\title{
Biodegradation of sulfamethoxazole: current knowledge and perspectives
}

\author{
Simone Larcher • Viviane Yargeau
}

Received: 6 June 2012 / Revised: 18 July 2012 / Accepted: 18 July 2012 / Published online: 17 August 2012

(C) Springer-Verlag 2012

\begin{abstract}
Antibiotic compounds, like sulfamethoxazole (SMX), have become a concern in the aquatic environment due to the potential development of antibacterial resistances. Due to extensive consumption, excretion and disposal, SMX has been frequently detected in wastewaters and surface waters. This has led to numerous studies investigating the nature of SMX, with many researchers focusing on the biodegradation and persistence of SMX during wastewater treatment and in the environment. This review provides a summary of recent developments, outlines the discrepancies in observations and results, and demonstrates the need for further research to determine optimal biological removal strategies for SMX and other antibiotics.
\end{abstract}

Keywords Sulfamethoxazole (SMX) · Biodegradation · Antibiotic $\cdot$ Wastewater $\cdot$ Metabolites $\cdot$ Environment

\section{Introduction}

SMX usage and presence in the environment

The widespread use and disposal of antibiotic compounds has led to concerns regarding their occurrence and fate in the aquatic environment (Allen et al. 2010) and the resulting exposure to wildlife and humans leading to long-term health effects (Ankley et al. 2007). The greatest anxiety is that their

\footnotetext{
S. Larcher $\cdot$ V. Yargeau $(\bowtie)$

Department of Chemical Engineering, McGill University, 3610 University Street,

Montréal, QC, Canada H3A 2B2

e-mail: viviane.yargeau@mcgill.ca

S. Larcher

e-mail: simone.larcher@mail.mcgill.ca
}

presence will lead to antibacterial resistance in biological wastewater (WW) treatment and the environment (Andersson 2003; Costanzo et al. 2005; Daughton 2003; Daughton and Ternes 1999; Goni-Urriza et al. 2000; Halling-Sorensen et al. 1998; Kümmerer 2009b; Reinthaler et al. 2003; Volkmann et al. 2004). Recently, this has been demonstrated by the observed increase in antibacterial resistance in Acinetobacter spp. isolates discharged to the environment after conventional activated sludge (CAS) WW treatment (Zhang et al. 2009) and the detection of antibiotic resistance genes in surface water to which highly treated municipal WW is discharged (LaPara et al. 2011). The estimated antibiotic consumption worldwide ranges from 100,000 to 200,000 $t$ annually (Wise 2002), and due to excretion (which can reach up to $90 \%$ of the ingested amount both as the original parent compound or as metabolites) (Daughton and Ternes 1999; Kümmerer 2009c) and disposal, up to microgram-per-liter levels have been detected in untreated WW (Hirsch et al. 1999; Kümmerer 2009a, c, b; Perez et al. 2005).

After the $\beta$-lactam class of compounds (consisting of penicillin amongst others), sulfonamides are the most commonly used antibiotics in most countries (Kümmerer 2009a) due to their ability to inhibit gram-positive and gramnegative bacteria, as well as protozoa (Zhang et al. 2009). The synthetic compound sulfamethoxazole (SMX) is one of the most popularly prescribed and consumed sulfonamide antibiotics (Cavallucci 2007; Hruska and Franek 2012) leading to its presence in the aquatic environment via WW discharge (Avisar et al. 2009; Santos et al. 2010) and its frequent detection in WWs at up to microgram-per-liter levels and surface waters at nanogram-per-liter levels (Batt et al. 2007; Benotti et al. 2009; Joss et al. 2005; Kolpin et al. 2002; Miège et al. 2009; Peng et al. 2006; Yargeau et al. 2007; Gao et al. 2012a). At these concentrations, SMX has been found to be mutagenic but not acutely toxic to Vibrio 
fisheri and Daphnia magna (Isidori et al. 2005) and to be phytotoxic to algae (García-Galán et al. 2011) and other plant species (Hillis et al. 2011). Several studies have measured a resistance to SMX in bacteria isolated from biological WW treatment (Costanzo et al. 2005; Reinthaler et al. 2003), which has raised concerns regarding the prevalence of SMX in WWs leading to the development of bacterial resistance in the aquatic environment. These concerns have been validated recently by the detection of sulfonamide resistance genes in river water (which was correlated to the total SMX concentration among other sulfonamides) (Luo et al. 2010) and the prevalence of SMX-resistant bacteria in aquaculture environments (Gao et al. 2012b).

Scope of this article

This article aims to provide an overview and summary of the current knowledge of SMX biodegradation based on the published results of studies carried out to date. Although previous review articles have focused on the input, occurrence, fate, and effects of antibiotics in the environment (Kümmerer 2009a) and the biodegradation of a wide array of pharmaceutical compounds (in WW treatment and in the environment) (Onesios et al. 2009), this is the first review to provide an overview and analysis of the knowledge on the biodegradation of SMX.

\section{Biodegradation of SMX}

As mentioned in the "Scope of this article," a relatively recent review of pharmaceutical biodegradation was published in which SMX was discussed (Onesios et al. 2009). A thorough summary of the published literature was provided at the time, which highlighted the variability in biological removal of SMX observed in the different systems studied (lab-, pilot-, and full-scale, conventional WW treatment; membrane bioreactor (MBR); sequencing batch reactor (SBR); and anaerobic digester) ranging from negative (due to SMX being re-formed from its metabolites and conjugates) to $99 \%$ removal. The authors attributed the discrepancies in the reported removals to differences in: experimental endpoints, initial compound concentration, incubation times and conditions, and microbial inoculum sources. The current paper includes the most relevant results published prior to 2009 but is focused primarily on the more recent developments in the area of SMX biodegradation. The review is divided into three sections focusing on aerobic degradation, anaerobic degradation and the ability of specific bacterial species to degrade SMX and concludes with an outlook on future SMX biodegradation research.
Aerobic degradation

\section{Removal using inoculum from activated sludge}

The majority of aerobic degradation studies have used activated sludge (AS) as the microbial inoculum in order to estimate the potential SMX degradation during WW treatment. Initially, standard laboratory tests were carried out in order to quickly and easily gain general insight into the biodegradability of SMX. As the sole carbon source, SMX was found to be not readily biodegradable using the OECD Closed Bottle Test at an initial concentration of $35 \mu \mathrm{g} / \mathrm{L}$ (AlAhmad et al. 1999; Alexy et al. 2004); however at a higher initial concentration $(3.8 \mathrm{mg} / \mathrm{L}), 13 \%$ was degraded in the presence of an added carbon source (sodium acetate) (Alexy et al. 2004). Using the Zahn-Wellens Test and the $\mathrm{CO}_{2}$ evolution test, $200 \mathrm{mg} / \mathrm{L}$ SMX was also found to be not-readily biodegradable (Gartiser et al. 2007). Researchers progressed towards the use of batch tests in an effort to more accurately model SMX degradation trends during biological WW treatment at lab scale. The results of earlier and recent batch tests using inoculum from AS from municipal wastewater treatment plants (WWTPs) have been inconsistent. While one study measured $<20 \%$ biodegradation after $48 \mathrm{~h}(3 \mu \mathrm{g} / \mathrm{L}$ initial SMX; 7.5 L reactor volume) (Joss et al. 2006), others observed 22 to $39 \%$ removal after $48 \mathrm{~h}(100 \mu \mathrm{g} / \mathrm{L}$ initial SMX; $1 \mathrm{~L}$ reactor volume) (Li and Zhang 2010); 0, 30, and $40 \%$ removal after 8 days (depending on the type of BDOC; $1.6 \mu \mathrm{g} / \mathrm{L}$ initial SMX; 1.5 L reactor volume) (Lim et al. 2008); and no degradation (when additional carbon and nitrogen sources present) to complete SMX removal (in the absence of additional carbon and nitrogen) after 17 days in a 1-L SBR (20 to $383 \mathrm{mg} / \mathrm{L}$ initial SMX) (Drillia et al. 2005). The most recent batch tests have used AS inocula from food-processing WWTPs. Two of the three studies had a similar experimental set-up consisting of a 1-L batch reactor, 100 to $500 \mu \mathrm{g} / \mathrm{L}$ initial SMX concentration, and synthetic WW (Yang et al. 2011; Yu et al. 2011), yet vastly different results. This discrepancy might be explained by the use of immobilized cell biocarriers prepared by combining polymer and dry sludge in a 2:1 ratio ( $2.5 \mathrm{~cm}$ diameter) in the study by Yu et al. (2011). Without the immobilized cell biocarriers, $24 \%$ SMX was removed overall after $48 \mathrm{~h}(6.5 \%$ removal due to adsorption in the first $12 \mathrm{~h}$ ) (Yang et al. 2011). However, the use of immobilized cell biocarriers resulted in increased SMX removal via biodegradation (59\%) in addition to $31 \%$ removal via biosorption after 14 days (Yu et al. 2011). The third study using AS inoculum from a food-processing WWTP was carried out in a larger batch reactor (20 L), using synthetic WW, and $100 \mu \mathrm{g} / \mathrm{L}$ SMX. Complete elimination of SMX was observed after 14 days, with only $0.41 \pm 0.04 \%$ of the original mass fraction adsorbed to the AS (Yang et al. 2012). 
As discussed in the review by Onesios et al. (2009), there are large discrepancies in reported SMX removals via biodegradation which may be attributed to variation in experimental conditions, especially the use of different AS inocula with inconsistent microbial communities.

\section{Removal in MBRs}

In addition to batch tests investigating the use of AS alone, several studies have explored the capabilities of MBRs as an alternative to conventional biological WW treatment for the removal of SMX. Pilot-scale reactors have demonstrated consistent results with SMX removal rates ranging from 52 to $70 \%$ regardless of initial SMX concentration $(145 \mathrm{ng} / \mathrm{L}$ to $20 \mu \mathrm{g} / \mathrm{L})$ (Clara et al. 2005; Kim et al. 2007; Reif et al. 2008). Lab-scale MBR studies ( 9 and 14 L) have demonstrated SMX degradation as a function of $\mathrm{pH}$ and powdered activated carbon (PAC) dose. Ninety percent SMX removal (2 to $20 \mu \mathrm{g} / \mathrm{L}$ initial SMX) occurred at pH 5 to 7 , and this decreased to $70 \%$ as the $\mathrm{pH}$ increased to 9 (Tadkaew et al. 2010). Without PAC addition, $64 \pm 7 \%$ SMX was removed, while with $1 \mathrm{mg} / \mathrm{L}$ PAC, the SMX removal increased to $82 \pm 11 \%(750 \mu \mathrm{g} / \mathrm{L}$ initial SMX); this was attributed to adsorption to the PAC ( $\mathrm{Li}$ et al. 2011). Another study demonstrated that using biogenic manganese oxides in a lab-scale MBR $(30 \mathrm{~L})$ removed 34 to $52 \%$ of the SMX from the secondary effluent of a WWTP (Forrez et al. 2011). The results of these studies seem to have more consistent SMX removals compared with the batch studies using AS alone, which may be due to the role played by the membrane technology employed. Thus, implementing MBRs for SMX removal during WW treatment might be an interesting option to consider in order to design a process with increased reliability and consistency.

\section{Removal in full-scale WWTPs based on AS}

Another study investigated the biodegradation of $20 \mu \mathrm{g} / \mathrm{L}$ SMX during the different treatment processes in a conventional WWTP instead of focusing solely on the role played by AS. Effluent samples (4 L) taken from primary clarification (S1), AS (S2), secondary clarification (S3), and final chlorine disinfection (S4) were analyzed separately in batch reactors in the laboratory (Perez et al. 2005). In all but S4 effluent, 80 to $90 \%$ SMX removal was achieved, with the fastest degradation occurring in S2 effluent ( $80 \%$ removal after 3 days compared with 25 days in $\mathrm{S} 1$ and 15 days in $\mathrm{S} 3$ effluent). This suggests that during conventional WW treatment, the AS process may be more responsible for the overall SMX removal achieved during the hydraulic retention time (HRT) of the WWTP.

With the understanding that the majority of SMX removal occurs during the AS process, the SMX concentration has been monitored/measured in full-scale WWTPs specifically focusing on the removal occurring in the biological treatment units. As reported for experiments conducted in the laboratory and at pilot scale, the results of full-scale WWTPs have varied widely (Table 1). A study monitoring the soluble SMX in the influent and effluent of the biological treatment units of two WWTPs (CAS, MBR, and fixed bed reactor) observed no significant change in SMX concentration due to biological treatment and assumed minimal adsorption based on known $K_{\mathrm{d}}$ values. However, when the SMX was considered in the form of the human metabolite $N_{4}$-acetyl-SMX, the biological removal ranged from 60 to $90 \%$. This study also determined that the observed removals were not dependent on the reactor configuration, sludge age, or temperature of the systems investigated (Joss et al. 2005). Another study measured an increase in SMX concentration after full-scale biological WW treatment, which was attributed to deconjugation processes resulting in SMX being re-formed from its human metabolites. However, this could not be confirmed as the metabolites were not monitored (Plósz et al. 2010). The most recent investigation has found that of the $90 \%$ SMX removal achieved overall during conventional WW treatment, approximately $50 \%$ can be attributed to biological treatment/AS with no significant sorption to sludge (Gao et al. 2012a). Again, the variation in the observed SMX removals may be attributed to differences in: microbial community of the AS systems, treatment plant operation (SRT and HRT), sampling methods (automated vs. grab sampling; frequency), and times (seasonal variation). The results of Joss et al. (2005) and Plósz et al. (2010) illustrate the potential importance of monitoring the human metabolite $N_{4}$-acetyl-SMX in order to gain a more complete perspective on SMX degradation during WW treatment, which may help to explain the reported differences in removal efficiencies. The importance of sampling strategy in determining accurate estimates of pharmaceutical removals in WWTPs has recently been discussed by researchers, noting that the commonly used 24$\mathrm{h}$ composite samples (with the effluent sampling time shifted by the mean HRT of the treatment system) ignore the mixing regime characteristics, flow, and concentration variability. This often results in variable removal rates as illustrated by the comparison of full-scale SMX monitoring studies in Table 1 . In order to avoid biased estimates and negative elimination efficiencies, the use of a sampling strategy that takes into consideration the hydraulic residence time distribution of WWTPs has been proposed (Majewsky et al. 2011a). While the differences in the microbial communities of AS systems can lead to variable SMX removals, the active fraction of AS has also been shown to impact the biodegradation of SMX in full-scale systems and should be considered in future studies (Majewsky et al. 2011b). 


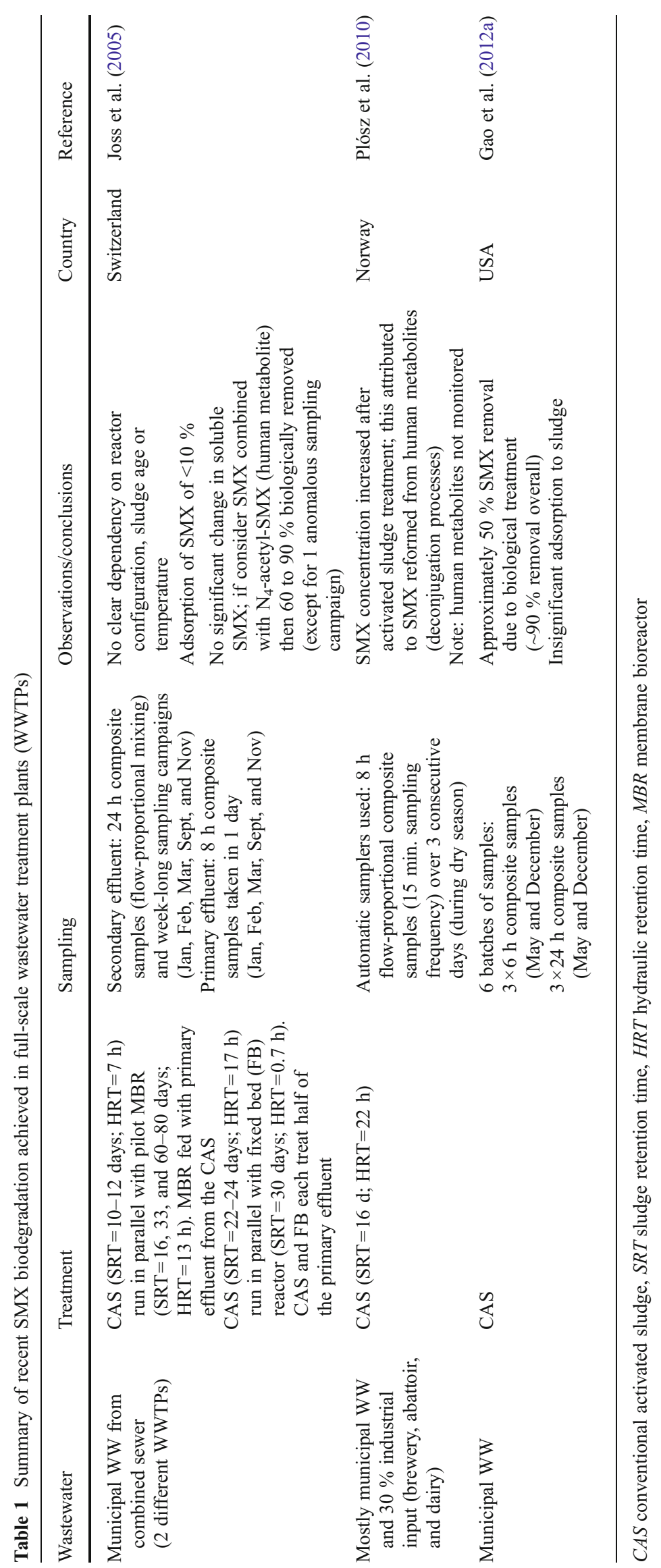


Biotransformation in the environment

In addition to the studies focused on the biodegradation of SMX during WW treatment, there have been tests carried out to investigate the fate of SMX under various environmental conditions (i.e., surface waters and soils) without using AS as inoculum. Three water-sediment studies (batch and continuous column) have been carried out to investigate SMX degradation in a simulated river bank environment. The first batch test used samples of river sediment ( $3 \mathrm{~g}$ dry weight) and river water $(60 \mathrm{~mL})$ spiked with $20 \mu \mathrm{g} / \mathrm{L} \mathrm{SMX}$ and resulted in $10 \%$ SMX degradation after 30 days $(\sim 25 \mathrm{~h}$ half-life); this increased to $22 \%$ removal in the presence of methanol, which served as an added carbon source $(\sim 10 \mathrm{~h}$ half-life) (Radke et al. 2009). The second batch test (discussed in more detail in the "Success of individual microorganisms") also used river sediment and water but evaluated higher SMX concentrations (1 to $20 \mathrm{mg} / \mathrm{L}$ ); the observed SMX removals ranged from 40 to $90 \%$ (Xu et al. 2011). The column test ( $2 \mathrm{~m}$ filter bed height, $0.155 \mathrm{~m}$ diameter) used technical quartz sand loaded with surface water containing 0.25 or $4.5 \mu \mathrm{g} / \mathrm{L} \operatorname{SMX}(0.13 \mathrm{~m} /$ days, 14 days HRT) and resulted in $60 \%$ SMX removal after 14 days exposure to $0.25 \mu \mathrm{g} / \mathrm{L} \mathrm{SMX}$ and $90 \%$ removal after 3.5 days exposure to $4.5 \mu \mathrm{g} / \mathrm{L}$ SMX. The estimated SMX half-life under these conditions ranged from 1 to 9 days (Baumgarten et al. 2011). This experiment was also carried out under anoxic and anaerobic conditions, which will be discussed in the following section. Another set of batch soil tests was conducted with water containing SMX combined with four other pharmaceutical compounds in order to assess the risk of irrigation with recycled water $(5 \mathrm{~g}$ soil, $40 \mu \mathrm{g}$ $\mathrm{SMX} / \mathrm{kg}$ soil). The results showed that sorption of SMX was negligible but biological degradation was significant: 9 to 11.4 days half-life compared with 59 days in sterilized soil (Lin and Gan 2011). This was also carried out under anaerobic conditions, as discussed in the following section.

Batch tests were also carried out with WW-impacted coastal/estuary seawater using a mixture of SMX +18 other pharmaceutical compounds $(1 \mu \mathrm{g} / \mathrm{L}$ each); the loss of pharmaceutical concentration over time was attributed to microbial degradation (compared with controls). SMX was one of the five most persistent pharmaceuticals tested with a halflife of 85 to $>100$ days, and it was suggested by these researchers that SMX would be a good candidate for a WW tracer (Benotti and Brownawell 2009). However, as discussed previously, SMX removal during WW treatment is highly variable and can be quite significant under certain conditions (Table 1) therefore caution should be employed when considering the use of SMX as a tracer.

Finally, a large-scale surface water microcosm study (12,000 L) was carried out containing aquatic communities consisting of fish, aquatic plants, zooplankton, phytoplankton, macrophytes, and bacteria. This study investigated the biodegradation of mixtures of eight pharmaceutical compounds including SMX (0.3 to $183 \mu \mathrm{g} / \mathrm{L})$. SMX was the second most persistent compound studied, with a half-life of 19 days (Lam et al. 2004).

The variability in the results of the studies mimicking environmental conditions may be due to the use of different surface water and soil samples, which would establish different microbial communities. This is similar to the variation in microorganisms resulting from the use of different AS samples. As well, different initial SMX concentration and the presence of other pharmaceutical compounds may have impacted the results if the other compounds were more readily degradable than SMX.

\section{Anaerobic degradation}

Although the majority of studies have focused on biological degradation of SMX under aerobic conditions, a few have investigated SMX biodegradation under anaerobic conditions. The results have demonstrated that anaerobic digestion (fermentation) is a very successful method to degrade SMX in sludge and manure with measured removal rates of $>99 \%$ after 10 to 35 days in batch-/lab-scale experiments. This impressive SMX degradation was achieved with both low (4 to $400 \mu \mathrm{g} / \mathrm{L}$ ) (Carballa et al. 2007) and high (2 to $10 \mathrm{mg} / \mathrm{L}$ ) (Mohring et al. 2009) initial SMX concentrations. In addition to these sludge and manure fermentation studies, anaerobic and anoxic column tests (as described in the previous section) were carried out with surface water containing 0.25 and $4.5 \mu \mathrm{g} / \mathrm{L} \mathrm{SMX}$ in order to model microbial degradation during bank filtration. The results showed no SMX degradation at the lower concentration $(0.25 \mu \mathrm{g} / \mathrm{L})$ but $27 \%$ removal (anoxic; 49-day half-life) and $51 \%$ removal (anaerobic; 16-day half-life) after 14 days at the higher SMX concentration $(4.5 \mu \mathrm{g} / \mathrm{L})$; these SMX removal rates are significantly less than those measured under aerobic conditions in the same study (see previous section) (Baumgarten et al. 2011). A batch test carried out in soil samples under anaerobic conditions with water containing SMX combined with four other pharmaceutical compounds (40 $\mu \mathrm{g} \mathrm{SMX} / \mathrm{kg}$ soil; described in previous section) resulted in a measured SMX half-life ranging from 15.3 to 18.3 days, which agrees with the results of Baumgarten et al. (2011). This is greater than the aerobic half-life but considerably less than the 59day half-life observed in sterilized soil and indicates successful biodegradation under anaerobic conditions (Lin and Gan 2011).

The results of the anaerobic degradation tests are encouraging and demonstrate that SMX may be removed biologically under anaerobic conditions both in the WW treatment and in the environment. Although limited, the results 
suggest that fermentation processes can achieve nearcomplete removal regardless of initial SMX concentration (in micrograms per liter or milligrams per liter), but degradation during bank filtration and in soils may not be as successful at lower SMX levels. Interestingly, the SMX removal (i.e., half-life) was similar in the soil investigations with or without the presence of other pharmaceutical compounds, which indicates that SMX may be degraded in real environments exposed to combinations of numerous types of pharmaceuticals.

\section{Success of individual microorganisms}

In the last several years, researchers have started to investigate the role of individual microorganisms during SMX degradation with the intention of optimizing its biological removal. A number of studies have demonstrated the ability of specific bacterial species to degrade SMX either through the use of pure cultures of individual bacteria or the isolation of strains from AS and biofilm. Table 2 provides a summary of the individual microorganisms that have demonstrated SMX-degrading capabilities while Table 3 outlines the metabolites of SMX degradation identified or proposed in the studies presented in the following paragraphs.
The most recent study conducted batch tests with high initial SMX concentrations (10 to $120 \mathrm{mg} / \mathrm{L}$ ) seeded with AS from a full-scale sewage treatment plant to initiate biofilm growth on hydroformylated fiber. The SMX removal and biological community were observed to depend on the experimental conditions tested: up to $64 \%$ SMX was removed after $8 \mathrm{~h}$ via biodegradation alone where the dominant bacterial strains isolated were Rhodopirrellula baltica and Methylibium petroleiphilum PM1; when biodegradation was combined with photolysis, complete SMX removal occurred after $4 \mathrm{~h}$ and the bacterial community consisted predominantly of Micrococcus luteus, Delftica acidovarasis, and Oligotropha carboxidovorans. It was assumed that this was due to the transformation of SMX to more biodegradable products during photolysis; however, this was not monitored or confirmed (Yan et al. 2012). Another recent study used inoculum from an established lab-scale MBR ( $52 \%$ average SMX removal) to seed batch tests investigating the extent of mineralization of $0.5 \mathrm{mM}(127 \mathrm{mg} / \mathrm{L})$ SMX. After 16 days, 24 to $44 \%$ SMX was mineralized and five bacterial strains were isolated from the successful aqueous matrix: Microbacterium sp., Rhodococcus sp., Achromobacter sp., Ralstonia sp. (two different strains), and Tsukumurella sp. (Bouju et al. 2012).

Table 2 Summary of individual microorganisms capable of degrading sulfamethoxazole (SMX)

\begin{tabular}{|c|c|c|c|c|c|}
\hline Species name & Type & Origin & Experimental conditions & Results/observations & Reference \\
\hline Rhodococcus rhodochrous & Bacteria & $\begin{array}{l}\text { Pure culture } \\
\quad(\text { ATCC 13808) }\end{array}$ & $\begin{array}{l}\text { Batch; MMSM; } 30 \mathrm{mg} / \mathrm{L} \\
\text { SMX }+3 \mathrm{~g} / \mathrm{L} \text { glucose }\end{array}$ & $20 \%$ SMX degradation & Gauthier et al. (2010) \\
\hline Bjerkandera adusta & Fungus & $\begin{array}{l}\text { Pure culture } \\
\quad \text { (ATCC 90940) }\end{array}$ & $\begin{array}{l}\text { Batch; } 10-10,000 \mathrm{U} / \mathrm{L} \\
\text { extracted versatile } \\
\text { peroxidase enzyme; } \\
33 \mu \mathrm{Mn}^{2+} ; 1-10 \mathrm{mM} \\
\text { sodium malonate; } \\
2.5 \mathrm{mg} / \mathrm{L} \text { SMX }\end{array}$ & $\begin{array}{l}64 \text { to } 80 \% \\
\text { SMX degradation }\end{array}$ & Eibes et al. (2011) \\
\hline Rhodococcus equi & Bacteria & $\begin{array}{l}\text { Pure culture } \\
\quad \text { (ATCC 13557) }\end{array}$ & $\begin{array}{l}\text { Batch; MMSM; } 6 \mathrm{mg} / \mathrm{L} \\
\mathrm{SMX} \pm 0.5 \mathrm{~g} / \mathrm{L} \text { glucose }\end{array}$ & $\begin{array}{l}15 \text { (no glucose) to } \\
29 \% \text { (with glucose) } \\
\text { SMX degradation }\end{array}$ & $\begin{array}{l}\text { Larcher and } \\
\text { Yargeau (2011) }\end{array}$ \\
\hline $\begin{array}{l}\text { Bacillus firmus } \\
\text { Bacillus cereus }\end{array}$ & Bacteria & $\begin{array}{l}\text { River water } \\
\text { and sediment }\end{array}$ & $\begin{array}{l}\text { Batch; river water and } \\
\text { sediment; 1-100 mg/L } \\
\text { SMX; 5-30 mg/L humic } \\
\text { acid (HA) }\end{array}$ & $\begin{array}{l}40.5 \text { to } 90 \% \\
\text { SMX degradation }\end{array}$ & $\mathrm{Xu}$ et al. (2011) \\
\hline $\begin{array}{l}\text { Microbacterium sp. (BR1) } \\
\text { Rhodococcus } \text { sp. (BR2) }\end{array}$ & \multirow[t]{4}{*}{ Bacteria } & \multirow[t]{4}{*}{ Lab-scale MBR } & \multirow[t]{4}{*}{$\begin{array}{l}\text { Batch; MMSM; } 0.5 \mathrm{mM} \\
(127 \mathrm{mg} / \mathrm{L}) \mathrm{SMX}\end{array}$} & \multirow[t]{4}{*}{$\begin{array}{l}24 \text { to } 44 \% \mathrm{SMX} \\
\text { mineralization }\end{array}$} & \multirow[t]{4}{*}{ Bouju et al. (2012) } \\
\hline Achromobacter sp. (BR3) & & & & & \\
\hline Ralstonia sp. (HB1, HB2) & & & & & \\
\hline Tsukumurella sp. (HB3) & & & & & \\
\hline $\begin{array}{l}\text { Rhodopirrellula baltica } \\
\text { Methylibium } \\
\text { petroleiphilum PM1 } \\
\text { Micrococcus luteus } \\
\text { Delftica acidovarasis } \\
\text { Oligotropha carboxidovarans }\end{array}$ & Bacteria & $\begin{array}{l}\text { Activated sludge } \\
\text { from full-scale } \\
\text { STP }\end{array}$ & $\begin{array}{l}\text { Batch; biofilm grown on } \\
\text { hydroformylated fiber; } \\
\text { 10-120 mg/L SMX; } \\
\text { photolysis tested in } \\
\text { addition to biodegradation }\end{array}$ & $\begin{array}{l}64 \% \text { (biodegradation) } \\
\text { to complete SMX } \\
\text { removal (biodegradation+ } \\
\text { photolysis) }\end{array}$ & Yan et al. (2012) \\
\hline
\end{tabular}

MMSM minimum mineral salt medium, MBR membrane bioreactor, STP sewage treatment plant 
Table 3 Summary of degradation products of sulfamethoxazole (SMX)

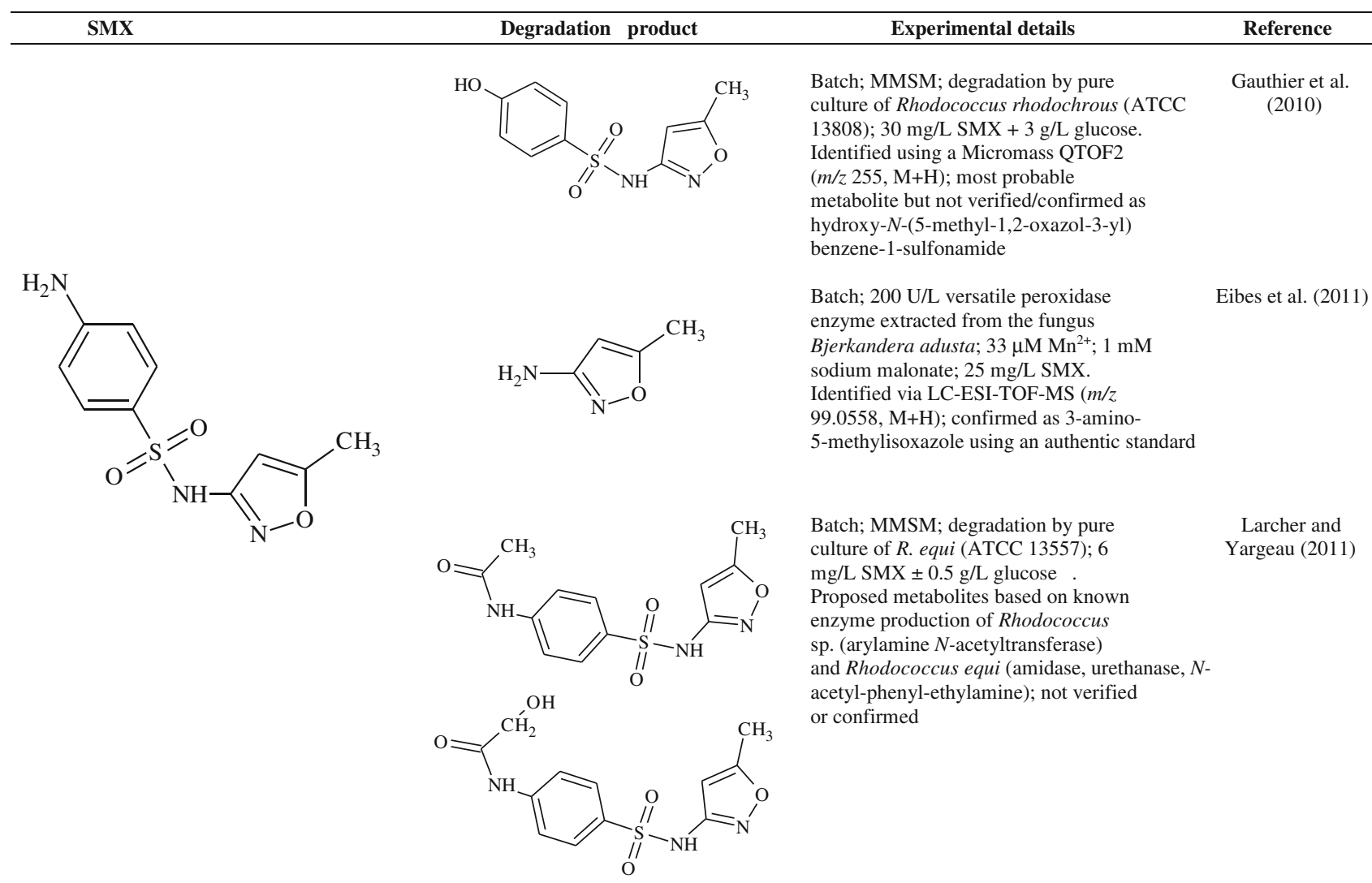

Batch experiments were also conducted using pure bacterial cultures in an aqueous matrix consisting of minimum mineral salt medium in order to determine the SMXdegrading efficacy of specific bacterial strains that have been previously isolated from biological WW treatment systems (Gauthier et al. 2010; Larcher and Yargeau 2011). One study focused on the ability of Rhodococcus rhodochrous and observed $20 \%$ SMX degradation only in the presence of glucose (30 mg/L SMX $+3 \mathrm{~g} / \mathrm{L}$ glucose); SMX was not removed when it was the sole carbon source. Several degradation products were detected, and the most probable identity (based on LC-MS analysis) of the one with the greatest stability and highest concentration was hydroxy$\mathrm{N}$-(5-methyl-1,2-oxazol-3-yl)benzene-1-sulfonamide (Gauthier et al. 2010). The second study investigated the SMX-degrading abilities of seven individual strains of bacteria in the presence and absence of glucose $(6 \mathrm{mg} / \mathrm{L} \mathrm{SMX} \pm$ $0.5 \mathrm{~g} / \mathrm{L}$ glucose): Bacillus subtilis, Pseudomonas aeruginosa, Pseudomonas putida, Rhodococcus equi, Rhodococcus erythropolis, Rhodococcus rhodochrous, and Rhodococcus zopfii. The results showed that SMX was successfully degraded by $R$. equi (15\% up to $29 \%$ removal with glucose) while the other six bacteria achieved minimal SMX degradation even with the addition of glucose $(<6 \%$ removal). A metabolite peak was consistently detected during HPLC analysis, and based on the enzymes known to be produced by Rhodococcus sp. and R. equi, it was proposed that the most likely degradation products would be an acetylated SMX compound or its alcohol derivative (Larcher and Yargeau 2011).

To simulate environmental conditions, batch tests using river water and sediment were employed to assess the biodegradation of high levels of SMX (1 to $20 \mathrm{mg} / \mathrm{L}$ ) at various temperatures (4 to $25^{\circ} \mathrm{C}$ ) and humic acid content (5 to $30 \mathrm{mg} / \mathrm{L}$ ). The SMX removal achieved ranged from 40 to $90 \%$, and two bacterial strains were isolated from the water-sediment system: Bacillus firmus and Bacillus cereus (Xu et al. 2011).

One recent study explored the efficacy of a versatile peroxidase (VP) enzyme extracted from a lignolytic fungus (Bjerkandera adusta) in the laboratory at batch scale $(100 \mathrm{~mL})$. The results demonstrated that 64 to $80 \%$ of the initial SMX $(2.5 \mathrm{mg} / \mathrm{L})$ was degraded after $7 \mathrm{~h}$. In addition, experiments conducted at a higher SMX concentration $(25 \mathrm{mg} / \mathrm{L})$ resulted in the detection of a metabolite identified and confirmed using an authentic standard as 3-amino-5methylisoxazole (Eibes et al. 2011).

Although exploratory and conducted using high initial SMX concentrations, these studies illustrate that certain 
types of bacteria may possess greater SMX-degrading capabilities. Rhodococcus sp. (especially $R$. equi and $R$. rhodochrous) have demonstrated these abilities in several different investigations under varying conditions aimed at modeling WW treatment, whereas two Bacillus sp. strains were identified in a river sediment study experiencing successful SMX degradation. Numerous other bacterial strains have also been identified in studies using AS inocula from WWTPs. Also, the fungus $B$. adusta has demonstrated the ability to degrade SMX via the VP enzyme. These results imply that specific individual bacterial species and fungi may play a more significant role in SMX degradation during WW treatment and in the environment, which may help to explain the variable results of experiments exploring the biological removal of SMX discussed in this review. Future investigations should identify the microorganisms present in successful studies in order to relate the specific type to the SMX removal achieved.

\section{Outlook/prospects for the future}

Based on the most recent developments, it is anticipated that future research will continue to focus on the microbial communities capable of degrading SMX, with an aim to isolate, identify, and harness the capabilities of individual microorganisms demonstrating the most success. This may lead to the use of specific bacteria and fungi to enhance the biodegradation of SMX during WW treatment. Also, as analytical techniques improve, the concentrations studied must be lower in order to represent the behavior of SMX at the part-per-trillion (nanogram-per-liter) levels commonly measured in WWs and surface waters. The majority of studies have been conducted at higher SMX concentrations (in micrograms per liter to milligrams per liter) for ease of analysis and experimentation; however, it will be necessary to verify the observations and results compiled thus far at more realistic SMX levels. Regarding WW treatment, as more membrane bioreactors (MBRs) are implemented in order to improve effluent quality, reduce sludge production, minimize the physical footprint requirement, and allow for future expansion flexibility, increased research investigating SMX removal during MBR treatment will be necessary. The recent pilot- and lab-scale studies have shown MBRs to be successful regardless of initial SMX concentration, $\mathrm{pH}$, or the addition of PAC or manganese oxides, making them potentially useful in the design of WW treatment facilities aiming to remove pharmaceutical compounds like SMX. Finally, the successful results of preliminary lab-scale tests exploring anaerobic degradation in sludge, manure, and environmental soil samples suggest further research should explore these SMX removal mechanisms in more depth.

\section{References}

Al-Ahmad A, Daschner FD, Kümmerer K (1999) Biodegradability of cefotiam, ciprofloxacin, meropenem, penicillin $\mathrm{G}$, and sulfamethoxazole and inhibition of waste water bacteria. Arch Environ Contam Toxicol 37(2):158-163

Alexy R, Kumpel T, Kummerer K (2004) Assessment of degradation of 18 antibiotics in the closed bottle test. Chemosphere 57 (6):505-512

Allen HK, Donato J, Wang HH, Cloud-Hansen KA, Davies J, Handelsman $J$ (2010) Call of the wild: antibiotic resistance genes in natural environments. Nat Rev Micro 8(4):251-259

Andersson DI (2003) Persistence of antibiotic resistant bacteria. Curr Opin Microbiol 6(5):452-456

Ankley GT, Brooks BW, Huggett DB, Sumpter JP (2007) Repeating history: pharmaceuticals in the environment. Environ Sci Tech 41 (24):8211-8217

Avisar D, Lester Y, Ronen D (2009) Sulfamethoxazole contamination of a deep phreatic aquifer. Sci Total Environ 407(14):4278-4282

Batt AL, Kim S, Aga DS (2007) Comparison of the occurrence of antibiotics in four full-scale wastewater treatment plants with varying designs and operations. Chemosphere 68(3):428-435

Baumgarten B, Jährig J, Reemtsma T, Jekel M (2011) Long term laboratory column experiments to simulate bank filtration: factors controlling removal of sulfamethoxazole. Water Res 45(1):211220

Benotti MJ, Brownawell BJ (2009) Microbial degradation of pharmaceuticals in estuarine and coastal seawater. Environ Pollut 157 (3):994-1002

Benotti MJ, Trenholm RA, Vanderford BJ, Holady JC, Stanford BD, Snyder SA (2009) Pharmaceuticals and endocrine disrupting compounds in U.S. drinking water. Environ Sci Tech 43(3):597-603

Bouju H, Ricken B, Beffa T, Corvini PF-X, Kolvenbach BA (2012) Isolation of bacterial strains capable of sulfamethoxazole mineralization from an acclimated membrane bioreactor. Appl Environ Microbiol 78(1):277-279

Carballa M, Omil F, Ternes T, Lema JM (2007) Fate of pharmaceutical and personal care products (PPCPs) during anaerobic digestion of sewage sludge. Water Res 41(10):2139-2150

Cavallucci S (2007) Top 200: What's topping the charts in prescription drugs this year? Pharmacy Practice, Canadian Healthcare Network. Available from http://www.imshealthcanada.com/vgn/ images/portal/cit 40000873/13/31/8286270612-TOP200-07final.pdf

Clara M, Strenn B, Gans O, Martinez E, Kreuzinger N, Kroiss H (2005) Removal of selected pharmaceuticals, fragrances and endocrine disrupting compounds in a membrane bioreactor and conventional wastewater treatment plants. Water Res 39 (19):4797-4807

Costanzo SD, Murby J, Bates J (2005) Ecosystem response to antibiotics entering the aquatic environment. Mar Pollut Bull 51(14):218-223

Daughton CG (2003) Chemicals from pharmaceuticals and personal care products, vol 1. Water: sciences and issues. MacMillan Reference, New York

Daughton CG, Ternes TA (1999) Pharmaceuticals and personal care products in the environment: agents of subtle change? Environ Health Perspect Suppl 107(S6):907-938

Drillia P, Dokianakis SN, Fountoulakis MS, Kornaros M, Stamatelatou $\mathrm{K}$, Lyberatos G (2005) On the occasional biodegradation of pharmaceuticals in the activated sludge process: the example of the antibiotic sulfamethoxazole. J Hazard Mater 122(3):259-265

Eibes G, Debernardi G, Feijoo G, Moreira M, Lema J (2011) Oxidation of pharmaceutically active compounds by a ligninolytic fungal peroxidase. Biodegradation 22(3):539-550 
Forrez I, Carballa M, Fink G, Wick A, Hennebel T, Vanhaecke L, Ternes T, Boon N, Verstraete W (2011) Biogenic metals for the oxidative and reductive removal of pharmaceuticals, biocides and iodinated contrast media in a polishing membrane bioreactor. Water Res 45(4):1763-1773

Gao P, Ding Y, Li H, Xagorakaki I (2012a) Occurence of pharmaceuticals in a municipal wastewater treatment plant: mass balance and removal processes. Chemosphere 37(7):17-24

Gao P, Mao D, Luo Y, Wang L, Xu B, Xu L (2012b) Occurrence of sulfonamide and tetracycline-resistant bacteria and resistance genes in aquaculture environment. Water Res 46(7):2355-2364

García-Galán MJ, Díaz-Cruz MS, Barceló D (2011) Occurrence of sulfonamide residues along the Ebro river basin: removal in wastewater treatment plants and environmental impact assessment. Environ Int 37(2):462-473

Gartiser S, Urich E, Alexy R, Kümmerer K (2007) Ultimate biodegradation and elimination of antibiotics in inherent tests. Chemosphere 67(3):604-613

Gauthier H, Yargeau V, Cooper DG (2010) Biodegradation of pharmaceuticals by Rhodococcus rhodochrous and Aspergillus niger by co-metabolism. Sci Total Environ 408(7):1701-1706

Goni-Urriza M, Capdepuy M, Arpin C, Raymond N, Caumette P, Quentin C (2000) Impact of an urban effluent on antibiotic resistance of riverine Enterobacteriaceae and Aeromonas spp. Appl Environ Microbiol 66(1):125-132

Halling-Sorensen B, Nors Nielsen S, Lanzky PF, Ingerslev F, Holten Lutzhoft HC, Jorgensen SE (1998) Occurrence, fate and effects of pharmaceutical substances in the environment-a review. Chemosphere 36(2):357-393

Hillis D, Fletcher J, Solomon K, Sibley P (2011) Effects of ten antibiotics on seed germination and root elongation in three plant species. Arch Environ Contam Toxicol 60(2):220-232

Hirsch R, Ternes T, Haberer K, Kratz K-L (1999) Occurrence of antibiotics in the aquatic environment. Sci Total Environ 225(12):109-118

Hruska K, Franek M (2012) Sulfonamides in the environment: a review and a case report. Vet Med 57(1):1-35

Isidori M, Lavorgna M, Nardelli A, Pascarella L, Parrella A (2005) Toxic and genotoxic evaluation of six antibiotics on non-target organisms. Sci Total Environ 346(1-3):87-98

Joss A, Keller E, Alder AC, Göbel A, McArdell CS, Ternes T, Siegrist $\mathrm{H}$ (2005) Removal of pharmaceuticals and fragrances in biological wastewater treatment. Water Res 39(14):3139-3152

Joss A, Zabczynski S, Gobel A, Hoffmann B, Loffler D, McArdell CS, Ternes TA, Thomsen A, Siegrist H (2006) Biological degradation of pharmaceuticals in municipal wastewater treatment: proposing a classification scheme. Water Res 40(8):1686-1696

Kim SD, Cho J, Kim IS, Vanderford BJ, Snyder SA (2007) Occurrence and removal of pharmaceuticals and endocrine disruptors in South Korean surface, drinking, and waste waters. Water Res 41(5):1013-1021

Kolpin DW, Furlong ET, Meyer MT, Thurman EM, Zaugg SD, Barber LB, Buxton HT (2002) Pharmaceuticals, hormones, and other organic wastewater contaminants in U.S. streams, 1999-2000: a national reconnaissance. Environ Sci Technol 36(6):1202-1211

Kümmerer K (2009a) Antibiotics in the aquatic environment-a review-part I. Chemosphere 75(4):417-434

Kümmerer K (2009b) Antibiotics in the aquatic environment - a review-part II. Chemosphere 75(4):435-441

Kümmerer K (2009c) The presence of pharmaceuticals in the environment due to human use-present knowledge and future challenges. J Environ Manag 90(8):2354-2366

Lam MW, Young CJ, Brain RA, Johnson DJ, Hanson MA, Wilson CJ, Richards SM, Solomon KR, Mabury SA (2004) Aquatic persistence of eight pharmaceuticals in a microcosm study. Environ Toxicol Chem 23(6):1431-1440
LaPara TM, Burch TR, McNamara PJ, Tan DT, Yan M, Eichmiller JJ (2011) Tertiary-treated municipal wastewater is a significant point source of antibiotic resistance genes into Duluth-Superior Harbor. Environ Sci Tech 45(22):9543-9549

Larcher S, Yargeau V (2011) Biodegradation of sulfamethoxazole by individual and mixed bacteria. Appl Microbiol Biotechnol 91 (1):211-218

Li B, Zhang T (2010) Biodegradation and adsorption of antibiotics in the activated sludge process. Environ Sci Tech 44(9):3468-3473

Li X, Hai FI, Nghiem LD (2011) Simultaneous activated carbon adsorption within a membrane bioreactor for an enhanced micropollutant removal. Bioresour Technol 102(9):5319-5324

Lim M-H, Snyder SA, Sedlak DL (2008) Use of biodegradable dissolved organic carbon (BDOC) to assess the potential for transformation of wastewater-derived contaminants in surface waters. Water Res 42(12):2943-2952

Lin K, Gan J (2011) Sorption and degradation of wastewaterassociated non-steroidal anti-inflammatory drugs and antibiotics in soils. Chemosphere 83(3):240-246

Luo Y, Mao D, Rysz M, Zhou Q, Zhang H, Xu L, Alvarez PJJ (2010) Trends in antibiotic resistance genes occurrence in the Haihe River, China. Environ Sci Tech 44(19):7220-7225

Majewsky M, Gallé T, Bayerle M, Goel R, Fischer K, Vanrolleghem PA (2011a) Xenobiotic removal efficiencies in wastewater treatment plants: residence time distributions as a guiding principle for sampling strategies. Water Res 45(18):6152-6162

Majewsky M, Gallé T, Yargeau V, Fischer K (2011b) Active heterotrophic biomass and sludge retention time (SRT) as determining factors for biodegradation kinetics of pharmaceuticals in activated sludge. Bioresour Technol 102(16):7415-7421

Miège C, Choubert JM, Ribeiro L, Eusèbe M, Coquery M (2009) Fate of pharmaceuticals and personal care products in wastewater treatment plants - conception of a database and first results. Environ Pollut 157(5):1721-1726

Mohring SAI, Strzysch I, Fernandes MR, Kiffmeyer TK, Tuerk J, Hamscher G (2009) Degradation and elimination of various sulfonamides during anaerobic fermentation: a promising step on the way to sustainable pharmacy? Environ Sci Tech 43(7):2569-2574

Onesios K, Yu J, Bouwer E (2009) Biodegradation and removal of pharmaceuticals and personal care products in treatment systems: a review. Biodegradation 20(4):441-466

Peng X, Wang Z, Kuang W, Tan J, Li K (2006) A preliminary study on the occurrence and behavior of sulfonamides, ofloxacin and chloramphenicol antimicrobials in wastewaters of two sewage treatment plants in Guangzhou, China. Sci Total Environ 371(13):314-322

Perez S, Eichhorn P, Aga DS (2005) Evaluating the biodegradability of sulfamethazine, sulfamethoxazole, sulfathiazole, and trimethoprim at different stages of sewage treatment. Environ Toxicol Chem 24(6):1361-1367

Plósz BG, Leknes H, Liltved H, Thomas KV (2010) Diurnal variations in the occurrence and the fate of hormones and antibiotics in activated sludge wastewater treatment in Oslo, Norway. Sci Total Environ 408(8):1915-1924

Radke M, Lauwigi C, Heinkele G, Murdter TE, Letzel M (2009) Fate of the antibiotic sulfamethoxazole and its two major human metabolites in a water sediment test. Environ Sci Technol 43 (9):3135-3141

Reif R, Suarez S, Omil F, Lema JM (2008) Fate of pharmaceuticals and cosmetic ingredients during the operation of a MBR treating sewage. Desalination 221(1-3):511-517

Reinthaler FF, Posch J, Feierl G, Wust G, Haas D, Ruckenbauer G, Mascher F, Marth E (2003) Antibiotic resistance of E. coli in sewage and sludge. Water Res 37(8):1685-1690

Santos LHMLM, Araújo AN, Fachini A, Pena A, Delerue-Matos C, Montenegro MCBSM (2010) Ecotoxicological aspects related to 
the presence of pharmaceuticals in the aquatic environment. $\mathrm{J}$ Hazard Mater 175(1-3):45-95

Tadkaew N, Sivakumar M, Khan SJ, McDonald JA, Nghiem LD (2010) Effect of mixed liquor $\mathrm{pH}$ on the removal of trace organic contaminants in a membrane bioreactor. Bioresour Technol 101 (5): $1494-1500$

Volkmann H, Schwartz T, Bischoff P, Kirchen S, Obst U (2004) Detection of clinically relevant antibiotic-resistance genes in municipal wastewater using real-time PCR (TaqMan). J Microbiol Methods 56(2):277-286

Wise R (2002) Antimicrobial resistance: priorities for action. J Antimicrob Chemother 49(4):585-586

Xu B, Mao D, Luo Y, Xu L (2011) Sulfamethoxazole biodegradation and biotransformation in the water-sediment system of a natural river. Bioresour Technol 102(14):7069-7076

Yan N, Xia S, Xu L, Zhu J, Zhang Y, Rittmann B (2012) Internal loop photobiodegradation reactor (ILPBR) for accelerated degradation of sulfamethoxazole (SMX). Appl Microbiol Biotechnol 94(2):527-535
Yang S-F, Lin C-F, Yu-Chen Lin A, Andy Hong P-K (2011) Sorption and biodegradation of sulfonamide antibiotics by activated sludge: experimental assessment using batch data obtained under aerobic conditions. Water Res 45(11):3389-3397

Yang S-F, Lin C-F, Wu C-J, Ng K-K, Yu-Chen Lin A, Andy Hong P-K (2012) Fate of sulfonamide antibiotics in contact with activated sludge - sorption and biodegradation. Water Res 46(4):13011308

Yargeau V, Lopata A, Metcalfe C (2007) Pharmaceuticals in the Yamaska River, Quebec, Canada. Water Qual Res J Can 42 (4):231-239

Yu T-H, Lin AY-C, Panchangam SC, Hong P-KA, Yang P-Y, Lin C-F (2011) Biodegradation and bio-sorption of antibiotics and nonsteroidal anti-inflammatory drugs using immobilized cell process. Chemosphere 84(9):1216-1222

Zhang Y, Marrs CF, Simon C, Xi C (2009) Wastewater treatment contributes to selective increase of antibiotic resistance among Acinetobacter spp. Sci Total Environ 407(12):3702-3706 